\title{
Tex-Cal Land Management, Inc. $v$. Agricultural Labor Relations Board: Administrative Adjudications and the Substantial Evidence Standard of Judicial Review
}

\section{In Tex-Cal Land Management, Inc. v. Agricultural Labor Relations}

Board ${ }^{1}$ an unanimous California Supreme Court ${ }^{2}$ upheld the constitutionality of a legislatively mandated substantial evidence standard of review of adjudicatory fact-findings made by a statewide agency. The opinion imphicitly disapproved the rationale underlying the court's conclusion in Bixby v. Pierno ${ }^{3}$ that agency fact-findings involving fundamental vested rights ${ }^{4}$ must be reweighed and sustained only if supported by the weight of the evidence in the court's independent judgment. Although the presence of both the substantial evidence and imdependent judgment standards of review in California's Code of Civil Procedure ${ }^{5}$ was not disturbed, it is now doubtful that the legislature is constitutionally required to maimtain both standards.

This Note traces the doctrinal origins of the Bixby rule and appraises the court's analysis in $\mathrm{Tex}$ - $\mathrm{Cal}$ in hight of that developinent. - Part I examines the existing law prior to the Tex-Cal decision. Part Il outlines that opinion, and is followed im Part III with an analysis of the assumptions underlying the court's dramatic shift from previous holdings. It concludes that a uniform substantial evidence standard is an attractive solution to a difficult procedural dilemma.

1. 24 Cal. 3d 335, 595 P.2d 579, 156 Cal. Rptr. 1 (1979) (Newman, J.) (6-0).

2. "Unanimous" may be an imprecise characterization of the court's disposition, since only Justices Mosk and Manuel flatly concurred. Acting Chief Justice Tobriner concurred "im the judgment"; Justices Richardson and Taylor concurred "in the result"; and Justice Clark, writing a dissent on other grounds, concurred "im the conclusions reached by the majority opinion." Id. at 356, 595 P.2d at 591, $156 \mathrm{Cal}$. Rptr. at 14. The "concurring" justices did not speciflcally articulate their various qualificatious.

3. 4 Cal. 3d 130, 481 P.2d 242, 93 Cal. Rptr. 234 (1971).

4. Such fundamental vested rights imclude the right to continue practicing one's profession, see, e.g., Yakov v. Board of Medical Examiners, 68 Cal. 2d 67, 435 P.2d 553, 64 Cal. Rptr. 785 (physician), and the right to continued welfare beneflts, Harlow v. Carleson, $16 \mathrm{Cal} .3 \mathrm{~d} 731,548$ P.2d 698, 129 Cal. Rptr. 298 (1976). See text accompanying notes 44-48 infra.

5. Cal. Civ. Proc. Code $\S 1094.5$ (West Supp. 1980). 


\section{LEGAL BACKGROUND}

Current views of the proper evidentiary standards for judicial review of administrative adjudications in California evolved from a consideration of separation of powers and due process principles. The developinent of the applicable case law culminated in Bixby v. Pierno, ${ }^{6}$ which stated the general rule in California prior to the Tex-Cal decision.

\section{A. Separation of Powers}

The supreme court has debated the proper standard to be applied by courts in reviewing administrative adjudications of state agencies ${ }^{7}$ since the court decided Standard Oil Co. v. State Board of Equalization in $1936 .{ }^{8}$ Review had previously been available by the traditional writs of certiorari ${ }^{9}$ and prohibition, ${ }^{10}$ which by their ternis only apply to the exercise of judicial functions. ${ }^{11}$ Because administrative agencies, though "not courts in the strict sense," nevertheless exercised "quasijudicial" functions, their adjudications lad been properly subject to these remedies. ${ }^{12}$ In Standard Oil, however, the court reasoned that since the California Constitution gave the legislature authority to vest judicial power solely im specified courts, ${ }^{13}$ the Board of Equalization did not have autliority to render a judicial decision. Rather than hold

6. 4 Cal. 3d 130, 481 P.2d 242, 93 Cal. Rptr. 234 (1971).

7. Until 1974, local agencies were given a special constitutional status by the court which immunized their decisions from constitutionally-compelled independent judgment review. See notes 13 and 32 infra. Also exempt are statewide agencies deriving judicial power directly from the constitution. See note 49 infra.

8. 6 Cal. 2d 557, 59 P.2d 119 (1936).

9. CAL. CIv. Proc. CODE $\$ 1068$ (West Supp. 1980).

10. Id. $\S 1102$ (West Supp. 1980).

11. Purely ministerial and legislative functions are reviewable by ordinary writ of mandamus. Id. $\S 1085$ (West Supp. 1980). This remedy may not be used to review adjudicatory decisious by agencies in which discretion has been vested by the legislature. State v. Superior Court, 12 Cal. 3d 237, 247 n.7, 524 P.2d 1281, 1287-88 n.7, 115 Cal. Rptr. 497, 503-04 n.7 (1974) (dictum). Declaratory rehef, Cal. CIv. Proc. CODE $\S 1060$ (West Supp. 1980), and injunction, Cal. CIv. Proc. Code $\$ \S 525-26$ (West Supp. 1980), are also available in this context. See W. DeErrng, CALIFornia ADministrative MandaMus $\$ 8$ 2.8-2.10 (1966 \& Supp. 1979) [hereinafter cited as DEERING].

12. Suckow v. Alderson, 182 Cal. 247, 250, 187 P. 965 , 966 (1920).

13. At that time the constitution provided that " $t$ t]he judicial power of the state shall be vested in the Senate, sitting as a court of impeachment, in a Supreme Court, district courts of appeal, superior courts, such mumicipal courts as may be established in any city or city and county, and such inferior courts as the Legislature may establish in any imcorporated city or town, township, county or city and county." CAL. Const. art. VI, § 1 (1879) (amended 1950). The "inferior courts" clause, later repealed, provided the basis of the court's assumption that local agencies might properly exercise judicial power and thus stand outside the scope of the Standard Oil holding. $6 \mathrm{Cal}$. 2d at 560, 59 P.2d at 120 (1936). 
that the legislature had in fact unconstitutionally conferred such power, or that the board had exercised it, the court concluded that the board's adjudication inust not have been "judicial." Certiorari was therefore not deened the proper writ. The following year the court apphed the same analysis to the writ of prohibition, holding that the remedy was not available to review a hicense revocation by a state agency. ${ }^{14}$

Two years later an unanimous court filled the procedural gap created by these two decisions. In Drummey v. State Board of Funeral Directors ${ }^{15}$ the court held that inandanus, which "was invented to provide a reinedy where no other renedy existed,"16 was proper in cases of hicense revocation by statewide agencies. Having settled on the mandamus remedy, however, the court declined to reaffirm the traditional scope of review of administrative factual findings, which in preStandard Oil certiorari proceedings had required the court to accept findings "if based on substantial although conflicting evidence." 17 Instead, Drummey held, the reviewing court "inust weigh the evidence, and exercise its independent judgment on the facts." 18

The Drummey court rested this result on two separate grounds. First, the separation of powers rationale of Standard Oil was thought to compel independent judicial reweighing of the evidence; otherwise "we would be necessarily holding that such board is exercising at least quasi-judicial powers. It is the essence of judicial action that finahity is given to findings based on conflicting evidence. If the statute be so construed it would violate the state Constitution." ${ }^{19}$ The Drummey court did not conteinplate a trial de novo, however; the board's findings "come before the court with a strong presumption of their correctness, and the burden rests on the complaining party to convince the court that the board's decision is contrary to the weight of the evidence."20 That the court qualified its independent judgment test with the inconsistent "strong presuinption" in favor of the board's findings imdicates a recognition, absent in Standard Oil, that agencies do exercise "judicial" functions. By distinguishing "judicial" as final action on conflicting evidence, the court preservcd its own authority, at the same time ap-

14. Whitten v. California State Bd. of Optometry, 8 Cal. 2d 444, 65 P.2d 1296 (1937).

15. 13 Cal. 2d 75, 87 P.2d 848 (1939). The Board had suspended Drummey's embalmer's hicense and Wilson's embalmer's and funeral director's licenses following notice and a hearing; the trial court issued writs of mandamus and, based on the record of the Board proceedings, reversed the order.

16. Id. at 82,87 P.2d at 852 .

17. Id. at 84,87 P.2d at 853 .

18. Id. (einphasis added).

19. Id.

20. Id. at 85,87 P.2d at 854 . 
proving the legislative delegation of "quasi-judicial" power to administrative agencies.

As a second basis of decision, the court rehed on the "jurisdictional" and "constitutional" fact doctrines announced in several decisions by the United States Supreme Court. In Crowell v. Benson, ${ }^{21}$ the federal Employees' Compensation Commission's jurisdiction in the case depended upon whether a inaster-servant relationship existed and whether the injury occurred on navigable waters. The Court held that these facts must be subject to independent judicial review because they determine the limits of the agency's constitutional power. In Ohio Valley Water Co. v. Ben Avon Borough ${ }^{22}$ and St. Joseph Stock Yards Co. v. United States, ${ }^{23}$ both rate-making cases, the Court ruled that the issue as to whether rates were unconstitutionally confiscatory inust be independently determined by the courts. These three cases were questionable exceptions to the established substantial evidence standard of judicial review of agencies in federal courts. ${ }^{24}$ Their application to the Drummey situation, where no excess of jurisdiction or unconstitutional property deprivation had been alleged, has been firmly criticized. ${ }^{25}$ Nevertheless, the analysis advanced in these decisions provided the framework for the due process approach subsequently taken by the California Supreme Court. To the extent tliat important rights have come to be protected by a more intrusive standard of review under the fundainental vested rights rule, the Ben Avon doctrine has retained its validity in California.

21. 285 U.S. 22 (1932)

22. 253 U.S. 287 (1920).

23. 298 U.S. 38 (1936).

24. While the Supreme Court has not extended the doctrines, neither has it taken opportunities to explicitly overrule them, perhaps in the interest of retaining a device for the protection of civil rights. L. JAFFe, JuDICIAL CONTROL OF ADMINISTRATIVE ACTION 648-52 (1965) [hereinafter cited as JAFFE]. On the other hand, lower court decisions explicitly rejecting the doctrines have not been reversed by the Court. See K. Davis, Administrative Law of the Seventies $\S \S 29.08 \& 29.09$ (1976 \& 1978 Supp.). In one situation-that of deportation proceedings in which a claim of citizenship is made-the Crowell doctrine is still strong, requiring a de novo review of that claim. Agosto v. INS, 436 U.S. 748 (1978).

25. Bixby v. Piero, 4 Cal. 3d 130, 157-58, 481 P.2d 242, 261-62, 93 Cal. Rptr. 234, 253-54 (1971) (Burke, J., concurring); Temescal Water Co. v. Department of Pub. Works, 44 Cal. 2d. 90, 104-05, 280 P.2d 1, 9-10 (1955) (questioning California's acceptance of jurisdictional fact doctrine, and refusing to apply it); Dare v. Board of Medical Examiners, 21 Cal. 2d 790, 812-15, 136 P.2d 304, 316-18 (1943) (Traynor, J., concurring and dissenting); Laisne v. California State Bd. of Optometry, 19 Cal. 2d 831, 855-59, 123 P.2d 457, 470-72 (1942) (Gibson, C.J., dissenting); McGovney, Administrative Decisions and Court Review Thereof, in California, 29 CALIF. L. REv. 110 (1941). Moreover, the doctrines have not fared well in other states. See 2 F. COOPER, STATE ADMINISTRATIVE LAW 673-76 (1965) [hereinafter cited as COOPER]. 


\section{B. Due Process}

The Drummey court characterized license revocation as administrative deprivation of "an existing valuable privilege," 26 suggesting that the right to continued professional practice is a property right protected by the fourteenth amendment. Subsequent decisions narrowed the implications of this due process holding, lowever, by limiting Drummey to its facts.

In McDonough v. Goodcell, ${ }^{27}$ the State Insurance Commissioner had rejected the application for a bail bond license of a bondsman with a longstanding involvement in that business. Although the rejection effected a deprivation of an on-going busmess in a manner that paralleled the Drummey revocation, the McDonough court explained that the protected property in Drummey was possession of the license itself. Since McDonough had not already possessed a license, he was not deprived of a vested constitutional right and, therefore, was not entitled to an independent judgment review. ${ }^{28}$ Declaring the Drummey liolding "an exception to the general rule" and "not to be applicable otherwise,"29 the McDonough court firmly established a denial/revocation distinction. After McDonough, an aggrieved individual's access to the independent judgment standard of review turned on whether the right at stake had "vested."

The court's attempts to clarify the nature of the independent judgment review also depended upon due process principles. In Laisne $v$. California State Board of Optometry, ${ }^{30}$ the court interpreted Drummey as requiring a trial de novo of license revocations. Minimizing the import of the "strong presumption" in favor of agency findings announced in Drummey, the Laisne court asserted that "evidence" in the "weight of the evidence" (i.e., independent judgment) standard "conteinplated not only the record of the proceedings before the board, but

26. $13 \mathrm{Cal} .2 \mathrm{~d}$ at 84,87 P.2d at 853 .

27. $13 \mathrm{Cal}$. $2 \mathrm{~d} 741,91$ P.2d 1035 (1939). The case was decided only three months after Drummey.

28. Presumably the court would have reached the same result under a separation of powers analysis. Since the Drummey court had defined "judicial" power in terms of a final decision concerning cancellation or suspension of an existing hicense, $13 \mathrm{Cal} .2 \mathrm{~d}$ at 84, 87 P.2d at 853, the denial of a license was not "judicial" and therefore did not abrogate the limits of administrative authority under the constitution. The resulting denial/revocation double standard for a single type of deprivation, where the applicant has been in busmess for some time, has been criticized by justices and commentators. Southern Cal. Jockey Club, Inc. v. California Horse Racing Bd., 36 Cal. 2d 167, 179-82, 223 P.2d 1, 9-11 (1950) (Traynor, J., dissenting); Laisne v. California State Bd. of Optometry, 19 Cal. 2d 831, 869, 123 P.2d 457, 478 (1942) (Gibson, C.J., dissentimg); McGovney, supra note 25.

For the racy political circumstances surrounding the McDonough case, see Goldberg, The Constitutionality of Code of Civil Procedure Section 1094.5(d): Effuvium From An Old Fountainhead of Corruption, 11 PAC. L.J. 1, 31-33 (1979) [heremafter cited as Goldberg].

29. $13 \mathrm{Cal} .2 \mathrm{~d}$ at $753,91 \mathrm{P} .2 \mathrm{~d}$ at 1042 .

30. 19 Cal. 2d 831, 123 P.2d 457 (1942). 
such additional evidence as either party desired to introduce before the trial court."31 Even if the jurisdictional and constitutional fact doctrines had lost favor in the federal courts, the court held that the due process provisions of the California Constitution compel de novo judicial review since only enumerated courts have the "full exercise of judicial power."32 This power roughly translates into the authority to conclusively deprive a person of a vested property right. Absent de novo review by a court, "judicial" administrative fact-finding was deemed a denial of due process. ${ }^{33}$

The consequences of Laisne appeared in Dare v. Board of Medical Examiners the following year. ${ }^{34}$ Taking Laisne to an extreme, John Dare had refused to produce at trial the record of the board proceedings, msisting instead on a trial de novo including new findings of fact. ${ }^{35}$ The Dare court retrenched its Laisne conclusion, holding that independent judgment review is not a trial de novo. Although the trial court is not confined to the record made by the board, nor bound by the findings, ${ }^{36}$ it nevertheless must decide the case on all competent evidence, including the findings of the board. ${ }^{37}$

31. Id. at 843,123 P.2d at 464 .

32. Id. at 846, 123 P.2d at 466. Because the United States Constitution does not enumerate courts, but vests judicial power "in such inferior courts as the Congress may from time to time ordain and establish," federal administrative agencies could be classified as "inferior courts" and exercise conclusive judicial power without violating due process. A similar approach was taken in the separation of powers context toward the "inferior courts" language of California's Constitution, see note 13 supra, which differed in that it ouly applied to local courts. The strictly logical, though inconsistent, result was that hicense revocations by local agencies such as city councils would not be touched by reviewing courts if supported by substantial evidence, whereas those by statewide agencies would receive the conrt's independent judgment and would be upheld ouly if supported by the weight of the evidence. Walker v. City of San Gabriel, $20 \mathrm{Cal} .2 \mathrm{~d} 879,882-85$, 129 P.2d 349, 351-53 (1942) (Traynor, J., concurring).

33. The Laisne court also based its holding on the separation of powers arguinent found in Drummey. The impact of Laisne on later opinions in this line of cases origimates in the court's affirmation in Laisne of the due process principle in Drummey. The alternative reasoning is therefore not discussed here.

34. 21 Cal. 2d. 790, 136 P.2d 304 (1943).

35. Dare's case thus evoked little syinpathy from the court, since he had apparently made only a perfunctory showing before the board in anticipation of a full trial in superior court. $I d$. at 793-94, 136 P.2d at 306. In its opinion the supreme court emphasized the discretion of a trial court to deny a petition for a writ of inandamus, and warned that the presentation of a "skeleton" case by a petitioner before the board "should weigh heavily against him in his endeavor to invoke the equity powers of the court in his behalf in the mandainus proceeding." Id. at 796-97, 799, 136 P.2d at 307-08, 309.

36. The court noted several instances in which additional evidence might be adinitted in the trial court's discretion: (1) evidence improperly refused by the board; (2) evidence which with reasonable diligence could not have been produced before the board; (3) testimony for impeachment purposes when a witness' credibility is questioned. In addition, a party may object to mcompetent evidence received by the board. $\mathrm{Id}$. at 799-800, $136 \mathrm{P} .2 \mathrm{~d}$ at 309 .

37. This definition of the independent judgment test was perhaps a response to the imcreasing burden on trial court dockets. As the dissent pointed out, "the courts are already so overburdened with their own work that they may well be driven to avoid undertaking administra- 
As part of California's Administrative Procedure Act (APA), ${ }^{38}$ the legislature codified the Drummey-McDonough-Dare rule in section 1094.5 of the Code of Civil Procedure, creating the "administrative inandainus" reinedy. ${ }^{39}$ The writ is available to review final adjudications in which a hearing is required by law, whether or not the agency is specifically covered by the APA. ${ }^{40}$

By not specifying those cases in which the courts are "authorized by law" to reweigh the evidence, the legislature left the management of that complexity to the judiciary that had created it. The Drummey separation of powers argument should logically have led to independent judgınent review of all adjudications of statewide agencies, including hicense denials. Instead, the court shifted its emphasis to the due process rationale, which under $M c D o n o u g h$ required an independent judginent review only of deprivations of vested property rights. After the enactunent of section 1094.5, the court contmued to uphold the denial/revocation distinction, granting independent judgment review only where vested property rights were at stake. ${ }^{41}$

tive investigations either by denying the alternative or peremptory writ of mandamus or remanding the cases to the administrative boards." Id. at 806,136 P.2d at 313 .

38. CAL. Gov'T CoDE $\S \S 11370-11528$ (West 1966). Its promulgation in 1945 preceded that of the federal Administrative Procedure Act of 1946, Pub. L. No. 404, 60 Stat. 237 (1946) (codified at 5 U.S.C. $\$ 8551-559,701-706,1305,3344,4301,5335,5362,7521$ (1977 \& 1978 Supp.) and the Model State Administrative Procedure Act (1946) (revised 1961). The California Act provided for an internal decisionmaking procedure for statewide agencies, the most important aspect of which was the provision of independent hearing officers for administrative adjudications. See generally Hohreiter v. Garrison, 81 Cal. App. 2d 384, 184 P.2d 323 (1st Dist. 1947) (upholding constitutionality of CAL. GOV'T CODE $\S 11517$, providing that agency may adopt hearing officer's proposed decision without reading the record or hearing the case); Clarkson, The History of the California Administrative Procedure Act, 15 HASTINGs L.J. 237 (1963-64).

39. The Act provides that "[j]udicial review may be had by filing a petition for a writ of mandate in accordance with the provisions of the Code of Civil Procedure, subject, however, to the statutes relating to the particular agency." CAL. Gov'T CoDE $\S 11523$ (West 1966).

40. 5 Witkin, California Procedure $§ 214$ (2d ed. 1971 \& Supp. 1979); Deering, supra note 11 at $\S \S 2.1-2.15$.

The portion of section 1094.5 relevant to review of agency findings of fact reads as follows:

Where it is claimed that the findings are not supported by the evidence, in cases in which the court is authorized by law to exercise its imdependent judgment on the evidence, abuse of discretion is established if the court determines that the findings are not supported by the weight of evidence; and in all other cases, abuse of discretion is established if the court determines that the findings are not supported by substantial evidence in the light of the whole record.

Cal. CIv. Proc. CodE $\S 1094.5$ (West Supp. 1980) (emphasis added).

41. E.g., Merrill v. Department of Motor Vehicles, 71 Cal. 2d 907, 458 P.2d 33, 80 Cal. Rptr. 89 (1969) (demal of application for driver's hicense; no independent judgment); Yakov v. Board of Medical Examiners, 68 Cal. 2d 67, 435 P.2d 553, 64 Cal. Rptr. 785 (1968) (revocation of medical certificate; independent judgment); Southern Cal. Jockey Club, Inc. v. California Horse Racing Bd., 36 Cal. 2d 167, 223 P.2d 1 (1950) (denial of application for horse racing license; no independent judgment); Moran v. Board of Medical Examiners, 32 Cal. 2d 301, 196 P.2d 20 (1948) (revocation of physician's license, independent judgment). Ironically, the federal law origins of the due 


\section{The Bixby Rule}

In Bixby v. Pierno ${ }^{42}$ the court again limited the reach of independent judgment review. It dismissed the technical separation of powers problems raised in previous cases by acknowledging that the "quasiadjudicative powers" of agencies are "essential to cope with new complexities," especially in the area of economic regulation. ${ }^{43}$ Implicitly shifting these adjudicatory responsibilities to the agencies, the Bixby court defined the role of trial courts as guardians of the noneconomic interests of individuals underrepresented in the legislative and executive branclies. ${ }^{44}$ Accordingly, it held that administrative decisions that "substantially affect vested, fundamental rights" require the court's independent judgment on review. ${ }^{45}$

Although the court framed its opmion in terms of separation of powers, the Bixby analysis essentially follows the due process approach introduced in Drummey. The court stated that "[I]n determining whether the riglit is fundamental the courts do not alone weigli the economic aspect of it, but the effect of it in human terms and the importance of it to the individual in the life situation." 46 Thus the Bixby court, on the one hand, foreclosed soine applications of independent judginent review by requiring that protected rights be "fundainental," in contrast to purely economic vested interests such as the right to retain a driver's license. ${ }^{47}$ On the other hand, while the scope of review

process underpinnings of this double standard were debunked by the court during this time. See Temescal Water Co. v. Department of Pub. Works, 44 Cal. 2d 90, 280 P.2d 1 (1955).

42. 4 Cal. 3d 130, 481 P.2d 242, 93 Cal. Rptr. 234 (1971).

43. Id. at 142,481 P.2d at 250,93 Cal. Rptr. at 242.

44. The court's focus on ensuring representation of minority interests closely follows the federal expansion of due process requirements and judicial insistence upon proper agency cousideration of all interests affected by administrative decisions. See Stewart, The Reformation of American Administrative Law, 88 HARv. L. REv. 1667 (1975).

45. 4 Cal. 3d at 143, 481 P.2d at 251, 93 Cal. Rptr. at 243 (emphasis added).

46. Id. at 144, 481 P.2d at 252, 93 Cal. Rptr. at 244. The court did not define "fundamental rights" except to offer the "opportunity to contimue the practice of one's trade or profession" as an example. However, the court undercut the persuasiveness of its new protection rationale by upholding the vested/nonvested distinction: a profession apparently loses its status as a fundamental right if it has not yet been granted the imprimatur of a liceusing agency. Significantly, the court shifted its reasoning with respect to the "nonvested" rule from its original separation of powers/due process theory to an "agency expertise" argument. For hicense applications, "[c]ourts are relatively ill-equipped to determine whether an individual would be qualified, for example, to practice a particular profession or trade." Id. at 146, 481 P.2d at 253, 93 Cal. Rptr. at 245. In defeuse of independent judicial review of license revocations, the court raised the spectre of potential agency bias against the "independent thinker" or "unpopular protestant." Id. at 147, 481 P.2d at 254, $93 \mathrm{Cal}$. Rptr. at 246. Expertise and bias, lrowever, are central concerns in both licensing and revocation situations.

47. See McGue v. Sillas, 82 Cal. App. 3d 797, 147 Cal. Rptr. 354 (Ist Dist. 1978) (license suspension by Department of Motor Vehicles reviewed under substantial evidence test). The petitioners in Bixby were minority shareholders contesting a perimit granted to a close corporation to carry out a recapitalization plan beneficial to the controlling sharelıolders. The court decided that 
question had arisen primarily in the licensing context, the focus on "fundainental" rights in Bixby led to the application of independent judgment review to new rights such as employment and welfare benefits. ${ }^{48}$

At the time the court decided Tex-Cal, the administrative mandaunus remedy, codified in section 1094.5, was applicable to the decisions of all nonconstitutional ${ }^{49}$ local and statewide agencies that had factfinding duties in evidentiary learings required by law. Whether the reviewing court was "authorized by law" under section 1094.5 to use its independent judgment rather than the substantial evidence standard was determined by applying the Bixby fornnula. If the agency decision substantially affected a fundamental vested right, the reviewing court was required to exercise its independent judgment on the record, take

the minority had neither a fundamental nor a vested right. 4 Cal. $3 \mathrm{~d}$ at $147-48,481$ P.2d at 254-55, 93 Cal. Rptr. at 246-47.

48. See, e.g., Anton v. San Antomio Community Hosp., 19 Cal. 3d 802, 567 P.2d 1162, 140 Cal. Rptr. 442 (1977) (doctor's right to use hospital facilities); Dickey v. Retirement Bd., 16 Cal. 3d 745, 548 P.2d 689, 129 Cal. Rptr. 289 (1976) (full salary disability benefits); Harlow v. Carleson, 16 Cal. 3d 731, 548 P.2d 698, 129 Cal. Rptr. 298 (1976) (aid to the disabled benefits). Characterization as "fundamental" does not serve to expand the scope of review under the pre-Bixby "vested" test, because in all of these cases the right is also found to have vested. In addition, the distinction between vested and fundamental is cloudy; rights tend to be fundamental because they are vested. "[I]n determining whether the right is sufficiently basic and fundamental to justify independent judgment review, the courts have considered the degree to which that right is 'vested,' that is, already possessed by the individual" Bixby v. Pierno, 4 Cal. 3d at 146, 481 P.2d at 253, 93 Cal. Rptr. at 245 (1971).

In Anton v. San Antonio Community Hosp., 19 Cal. 3d 802, 567 P.2d 1162, 140 Cal. Rptr. 442 (1977), the court found that common law principles of procedural due process required that, prior to revocation of staff privileges at a private hospital, a doctor be given a hearing in which evidence is taken to support the board's decision. Since coustitutional due process provisions do not apply to private action, the court relied on long-standing California doctrines of "fair procedure" for this conclusion. See Note, Civil Procedure Code Section 1094.S: Threshold to Judicial Review of Private Agency Actions, 66 CALIF. L. REv. 201, 209-11 (1978). Once within the compass of section 1094.5 (an evidentiary hearing being "required by law," i.e, pursuant to standards set by the national Joint Commission on Accreditation of Hospitals), the court did not hesitate to extrapolate the Bixby-Strumsky line to require imdependent judgment review of decisions made by nongovernmental agencies which affect fundamental vested rights. The Bixby rule was thus severed from its separation of powers and due process origins, because neither of these doctrines applies to actions of nongovernmental entities. The Anton result was thus an unexpected extension of this doctrine from the governmental to the private arena. Significantly, in the following year the legislature amended section 1094.5 to exempt private hospital board decisions from independent judgment review unless the petitioner has alleged discrimination. Ch. 1348, \& 1, 1978 Cal. Stats. (currently codified at CAL. Civ. Proc. Code $\S 1094.5$ (d) (West Supp. 1980). See Goldberg, supra note 28.

49. The separation of powers clause provides that "[p]ersons charged with the exercise of one power may not exercise either of the others except as permitted by this Constitution." CaL. Const. art. III, \& 3 (emphasis added). See, e.g., Skelly v. State Personnel Bd., 15 Cal. 3d 194, 539 P.2d 774, 124 Cal. Rptr. 14 (1975); Kirby v. Alcohohic Beverage Control Appeals Bd., 7 Cal. 3d 433, 398 P.2d 1105, 102 Cal. Rptr. 857 (1972); Boreta Enterprises, Inc. v. Department of Alcoholic Beverage Control, 2 Cal. 3d 85, 465 P.2d 1, 84 Cal. Rptr. 113 (1970); Southern Cal. Jockey Club, Inc. v. California Horse Racing Bd., 36 Cal. 2d 167, 223 P.2d 1 (1950). 
additional evidence in limited circumstances, ${ }^{50}$ and find an abuse of discretion if the findings were not supported by the weight of the evidence. Otherwise, section 1094.5 required the court to examine the entire record and find an abuse of discretion only in the absence of substantial evidence. The Bixby principle culminated the court's gradual accession to the view that due process and separation of powers principles require an independent judicial review whenever particularly important rights are involved, in order to prevent the exercise of "judicial" power by administrative agencies.

\section{II.}

\section{The DeCISION}

The Umited Farin Workers (UFW) alleged that Tex-Cal, shortly after laying off a number of union and nonunion farmworkers during a seasonal lull in fall of 1975, had forcibly excluded five UFW organizers from its property. In addition to this charge, the UFW alleged that the lay-off of seven of its meinbers was illegally based on their union meinbership and sympathies, ${ }^{51}$ and that the exclusion violated their organizers' rights of access under regulations promulgated pursuant to the Agriculture Labor Relations Act (ALRA) ${ }^{52}$ The Agricultural Labor Relations Board (Board) issued a coinplaint, a hearing was held, and the administrative hearing officer issued findings, conclusions, and recommendations in favor of UFW on the lay-off charge but against it on the access charge. A three-member panel then issued its order in favor of UFW on both charges. The order restrained Tex-Cal froin its alleged unfair labor practices, ordered reinstatement of the illegally laid-off workers with reimbursement of lost wages, and prescribed a notice to be inailed, posted, and read to workers regarding the order and workers' rights under the ALRA. Tex-Cal appealed ${ }^{53}$ directly to

50. Section 1094.5 provides in part: "Where the court finds that there is relevant evidence which, in the exercise of reasonable diligence, could not have been produced or which was improperly excluded at the hearing before respondent, it may enter judginent as provided in subdivision ( $f$ ) of this section remanding the case to be reconsidered in the light of such evidence; or, in cases in which the conrt is authorized by law to exercise its independent judgment on the evidence, the court may admit such evidence at the hearing on the writ without remanding the case." CAI. Civ. Proc. Code § 1094.5(e) (West Supp. 1980). See also Dare v. Board of Medical Exanniners, 21 Cal. 2d 790, 799, 136 P.2d 304, 309 (1943).

51. It is an unfair labor practice for an agricultural employer, by "discrimination in regard to the hiring or tenure of einployment, or any term or condition of employinent, to encourage or discourage inembership in any labor organization." CAL. LAB. CoDE § 1153(c) (West Supp. 1980).

52. Id. at $\$ 1153$ (a) (West Snpp. 1980).

53. Tex-Cal only appealed the inailing and reading portions of the sanctions imposed by the Board. Tex-Cal Land Manageinent, Inc. v. ALRB, 144 Cal. Rptr. 149, 162 (5th Dist. 1978). At least two courts of appeal have limited application of the Bixby rule to cases in which the holder of the fnndamental vested right appeals an unfavorable agency decision, so that a favorable decision-because it thus presents no imperiled fundamental vested right at the appellate level-is 
the fifth district court of appeal, pursuant to statute ${ }^{54}$ Employing the substantial evidence standard required under the ALRA, ${ }^{55}$ the court of appeal sustained the Board's order with minor modifications. ${ }^{56}$

Despite the fact that the Board is a state agency lacking constitutionally conferred judicial power, ${ }^{57}$ the California Supreme Court concluded that the legislature has authority to limit judicial review to the substantial evidence standard. The court ruled that "[T]he Legislature may accord finality to the findings of a statewide agency that are supported by substantial evidence on the record considered as a whole and are made under safeguards equivalent to those provided by the ALRA for unfair labor practice proceedings, whether or not the California Constitution provides for that agency's exercising 'judicial power." "58 Second, it held that a court of appeal may properly take origimal jurisdiction in proceedings such as this because they are in the nature of mandamus, and inay summarily deny the writ at its discretion. Finally, the court found the board's decision to be supported by substantial evidence. $^{59}$ Only the first point is at issue here.

The court first recited the case law leading to the twin standard of review rule in section 1094.5 proceedings. ${ }^{60}$ The court did not overtly

reviewed under the substantial evidence test. Sierra Club v. California Coastal Zone Conservation Comm'n, 58 Cal. App. 3d 149, 129 Cal. Rptr. 743 (1st Dist. 1976), quoted in dictum in lnterstate Brands Corp. v. Unemployment Ins. Appeals Bd., No. L.A. 31113, slip op. at 17 (Cal. Apr. 10, 1980); Northern Inyo Hosp. v. Fair Employment Practices Comm'n, 38 Cal. App. 3d 14, 112 Cal. Rptr. 872 (4th Dist. 1974). If this is to be the rule, then presumably no fundamental vested right was at stake in Tex-Cal, and aspects of the opinion inupliedly overruling Bixby may be easily dismissed. But neither Bixby nor Strumsky indicates that scope of review should turn on which party prevailed below. The better rule focuses on the interest at stake at the agency level because, regardless of the outcome there, the agency's treatment of that interest is the subject of review in court. Moreover, slrould the court reverse the agency, the original victor's interest would again be infriniged. Under this approach, a fundamental vested right, i.e., to continued employment, was arguably at stake in Tex-Cal, and the Bixby rule was therefore iniplicated.

54. Cal. Lab. Code $\$ 1160.8$ (West Supp. 1980).

55. "The findings of the board with respect to questious of fact if supported by substantial evidence on the record considered as a whole shall in like manner be conclusive." Id.

56. 24 Cal. $3 d$ at 342, 352-54, 595 P.2d at 582-83, 589-90, 156 Cal. Rptr. at 4-5, 11-12.

57. It may in fact be argued that the Board does lave judicial power under the constitution: "The Legislature inay provide for minimum wages and for the general welfare of employees and for those purposes may confer on a commission legislative, executive, and judicial powers." CAL. ConsT. art. XIV, § 1. Power is not directly conferred, but the provision gives the legislature such authority. The problem raised in Strumsky, concerning the exclusive allocation by article VI, $\S 1$ of judicial power to courts is thus overcoine, because, unlike that case, the legislature in dealing with administration of employment rcgulations has an explicit independent constitutional source of authority. Perliaps in its eagerness to reacl its novel lolding, lowever, the supreine court ignored this approach, treating the Board as a statewide agency without judicial authority.

58. 24 Cal. 3d 346, 595 P.2d at 585, 156 Cal. Rptr. at 7 (1979).

59. On the merits, the court reviewed the Board's decision rather than that of the lower court. Since the Board was the "trial court," the court of appeal decision was ignored. See McDonough v. Goodcell, 13 Cal. 2d 741, 744-45, 91 P.2d 1035, 1038 (1939).

60. See Part I supra. 
disturb this rule. It failed, however, to directly address the underlying constitutional doctrines of judicial power and due process applied and developed in those cases. Instead, the Tex-Cal court made three policy arguinents for upholding the ALRA's single substantial evidence standard. ${ }^{61}$ The court's first policy arguinent was that the tested federal precedent and the elaborate procedural scheme of the ALRA obviated the need for a broader scope of review. Patterned after portions of the National Labor Relations Act, ${ }^{62}$ the ALRA requires the separation of prosecutorial froin adjudicatory functions; notice, written pleadings, evidentiary hearings, and findings based on a preponderance of the evidence on record; and direct review by a court of appeal using the substantial evidence standard. According to the court, it is California's version of "the proved federal instrumentality for protecting rights of einployees and einployers with respect to collective bargaining."63 The substantial evidence standard was a "deliberate legislative choice."64

61. As a point of departure the court focused on two ancillary matters in the Bixby opinion. In Bixby the court had stated that in section 1094.5 the legislature had granted authority to courts to determine how the two review standards should be applied; that, given this, "the court would now assert a doubtful prerogative if it were to rule that no cases at all require an independent judgment review and that the Legislature created an empty category in section 1094.5." 4 Cal. 3d at 140,481 P.2d at 249, 93 Cal. Rptr. at 241. At this point the Bixby court had added a footnote: "Furthermore, the guarantee of an independent judgment review lias often salvaged administrative procedures whiclt would otherwise violate due process of law . . . Id. n.6 (citations omitted). The Tex-Cal court coneluded that these sentences implied that the legislature itself could provide a single substantial evidence standard by statute, and that if the statute also guaranteed procedural due process it "might pass constitutional muster." 24 Cal. 3d at 344, 595 P.2d at 584, 156 Cal. Rptr. at 6.

The phrase "coustitutional muster" is confusing. In Bixby these two points were made at the conclusion of the court's introductory assertion that section 1094.5 authorized it to apply its in-

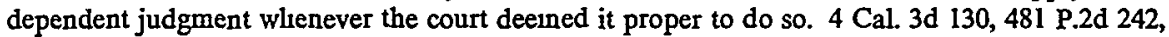
93 Cal. Rptr. 234. The critical constitutional arguinent came at a later point in the opinion, and is not addressed by the court in Tex-Cal.

Noting that none of the earlier cases liad invalidated such a statute, the court asserted that the constitutional doctrines detailed in those cases were "unnecessary to the loldings, which could as well have been grounded in judicially fashioned rules of procedure or in interpretation of section 1094.5." 24 Cal. 3d 345, 595 P.2d at 585, 156 Cal. Rptr. at 7. This stateinent is clearly in error since it treats the section 1094.5 rule as separate froun its rationale. Under previous holdings, whether the court is "authorized by law to exercise its independent judgment on the evidence," pursuant to section 1094.5, depends on the agency's judicial power under the constitution. In Bixby, for example, after discussing section 1094.5, the court declared "[i]n considering the appropriate standard of judicial review we begin our analysis with two constitutional provisions," article 111 and article VI, $\$ 1.4$ Cal. 3d at 141, 481 P.2d at 249, 93 Cal. Rptr. at 241 (emphasis added). Justice Clark, dissenting in Anton $\nu$. San Antonio Community Hosp., reiterated: "The constitutional basis asserted for the trial de novo rule is article VI, section 1 of our state Constitution, vesting judicial power in the courts." 19 Cal. 3d 802, 833, 567 P.2d 1162, 1180, 140 Cal. Rptr. 442, 460 (1977). Ignoring that reasoning, the $\mathrm{Tex}$-Cal court declined to create what it termed a "new" constitutional restriction. $24 \mathrm{Cal}$. 3d at 346, 595 P.2d at 585, 156 Cal. Rptr. at 7.

62. 29 U.S.C. $\$ \S 153,160$ (1977).

63. 24 Cal. $3 d$ at 345,595 P.2d at 584, 156 Cal. Rptr. at 6.

64. Id. at 345,595 P.2d at $585,156 \mathrm{Cal}$. Rptr. at 7 . 
Second, the court argued that the Board's expertise in labor relations surpassed that of the court and should be respected, as the legislature had intended. ${ }^{65}$ Third, the court observed that the wide range of sanctions available to the Board would make case by case determination of whether there had been a deprivation of a fundannental vested right "a prolific source of the hitigious delay that the Legislature indisputably sought to avoid." 66

The court's concern with the "prolific source" of delay is its admission that inany cases reviewed under the ALRA do involve fundamental vested rights which under section 1094.5 would warrant independent judgment on the evidence. The implicit conclusion is that even these cases receive adequate protection at the agency level, given the Board's detailed statutory procedures and estabhished coinpetence.

III

\section{ANALYSIS}

The Tex-Cal court avoided the constitutional issues inherent in the factual context of the case. ${ }^{67}$ Instead, it presented a pragmatic model of the relationship between court and agency in which agencies may exercise "judicial" powers to the extent that they also comply with procedural due process requirements. Within this framework, the Tex-Cal court suggested that due process does not require independent judgment review. In the aftermath of the $\mathrm{Tex}$-Cal opinion it therefore appears that no serious impediment remains to prevent the return to a single substantial evidence standard of review of administrative adjudications in California.

\section{A. "Judicial Power" and Due Process}

Under previous case law, a final agency adjudication involving a fundamental vested right is an exercise of judicial power and is there-

65. Id. at 346,595 P.2d at 585,156 Cal. Rptr. at 7 .

66. Id. Although not cited by Tex-Cal, previous opinions had argued that the lack of guidelines for identifying fundamental rights and vested rights, the additional time required to reweigh the evidence in independent judgment cases, and the increased likelihood of remand to the agency provided sufficient support for a single substantial evidence standard of review. See, e.g., Anton v. San Antonio Community Hosp., 19 Cal. 3d 802, 832, 567 P.2d 1162, 1180, 140 Cal. Rptr. 442, 460 (1977) (Clark, J., dissenting); Bixby v. Pierno, 4 Cal. 3d 130, 153, 159, 481 P.2d 242, 259, 263, 93 Cal. Rptr. 234, 250-51, 255 (1971) (Burke, J., concurring).

67. The court's clean avoidance of the constitutional issues raises the question of the vulncrability of the Tex-Cal opinion to future nodification should the court deen it necessary. One commentator has suggested that "[c]ertainly a doctrine which has become, rightly or wrongly, so enbedded in California constitutional law deserves a more decent extinction than suffocation by the legislature's desire to avoid delays of hitigation in a particular area." Goldberg, supra note 28, at 25 . 
fore subject to independent court decision. ${ }^{68}$ After Tex-Cal, however, the legislature nay give finality to sucl agency determinations based on substantial evidence, "whetler or not the California Constitution provides for that agency's exercising 'judicial power." "69 The court certainly could not liave intended to allow the legislature to give agencies judicial power where the constitution prohibits such vesting. But it inade no attempt in Tex-Cal to reconcile its previous loldings, nor to otherwise ground its decision in the constitution. ${ }^{70}$

The Drummey court concluded that "if fact-finding power is conferred on purely administrative boards, . . . then the party adversely affected, at least where constitutional rights are involved, las been deprived of due process." "71 "Judicial power" is therefore a conclusion of the Bixby test: The loss of a fundanental vested right "is too important to the individual to relegate it to exclusive administrative extinction." 72 Under Bixby, even the agency's "quasi-judicial" fact-findings are subject to the court's independent judgment review. It is this "judicial power" that the legislature conferred upon the Board in Tex-Cal by limitimg review to the substantial evidence standard in all cases. ${ }^{73}$ The

68. Prior to McDonough v. Goodcell, 13 Cal. 2d 741, 91 P.2d 1035 (1939), any final decision based on conflicting evidence was "judicial." See Drummey v. State Bd. of Funeral Directors, 13 Cal. 2d 75, 87 P.2d 848 (1939); Standard Oil Co. v. State Bd. of Equalization, 6 Cal. 2d 557, 59 P.2d 119 (1936). In McDonough the concept was restricted to final adjudication of constitutionally protected vested property rights, thus modifying the approach under CAL. ConST. art. VI, § 1. It was further limited by due process principles in Bixby to refer only to final decisions "substantially" affecting fundamental vested rights. 4 Cal. 3d 130, 143, 481 P.2d 242, 251, 93 Cal. Rptr. 234, 243 (1971). See text accompanying notes $26-48$ supra.

69. $24 \mathrm{Cal}$. 3d at 346,595 P.2d at $585,156 \mathrm{Cal}$. Rptr. at 7.

70. In support of the simgle substantial evidence standard in Tex-Cal, the court cited the sole use of that standard in reviewing decisions made by the Alcoholic Beverage Control Appeals Board and the Workmen's Compensation Appeals Board. Id. at 349, 595 P.2d at 587, 156 Cal. Rptr. at 9. The analogy was erroneous, however, because those agencies derive their judicial authority from explicit constitutional provisions. CAL. CONST. art. XX, $\$ 22$ (Alcoholic Beverage Control); CAL. CoNST. art. XIV, $\$ \$ 1$ \& 4 (Workmen's Compensation).

71. $13 \mathrm{Cal} .2 \mathrm{~d} 75,84,87$ P.2d 848, 853 (1939). Although the court was basing its statemcnt on federal precedents, it later ruled that the California Constitution required the same result. Laisne v. California State Bd. of Optometry, 19 Cal. 2d 831, 846, 123 P.2d 457, 466 (1942).

72. 4 Cal. 3d at 144, 481 P.2d at 252, 93 Cal. Rptr. at 244.

73. Prior to Strumsky v. San Diego County Einployees Retirement Ass'n, 11 Cal. 3d 28, 520 P.2d 29, 112 Cal. Rptr. 805 (1974), courts had assumed that local agencies could constitutionally exercise "judicial power" and were thus immune to searching court review of adjudications. See, e.g., Fascination, Inc. v. Hoover, 39 Cal. 2d 260, 246 P.2d 656 (1952); Walker v. City of San Gabriel, 20 Cal. 2d 879, 129 P.2d 349 (1942); Drummey v. State Bd. of Funeral Directors, 13 Cal. 2d 75, 87 P.2d 848 (1939); Standard Oil Co. v. State Bd. of Equalization, 6 Cal. 2d 557, 59 P.2d 119 (1936). This category somewhat irrationally included statewide agencies of local jurisdiction, such as water districts and school districts. See, e.g., Atchison, Topeka \& Santa Fe Ry. v. Kings County Water Dist., 47 Cal. 2d 140, 302 P.2d 1 (1956); DeERING, supra note 11, § 5.66; Kleps, Certiorarified Mandamus Reviewed: The Courts and California Administrative Decisions-1949. 1959, 12 Stan. L. Rev. 554, 561-62 (1960).

Constitutional authority was thought to be derived from article VI, $\S 1$, which was amended in 1950 to read: "The judicial power of the State is vested in the Supreme Court, courts of appeal, 
court's sanction of this delegation is necessarily a conclusion that independent judginent review is not required by due process.

superior courts, municipal courts, and justice courts. All except justice courts are courts of record." CAL. CoNsr. art. VI, $\S 1$. In Strumsky the court concluded that this amendmcnt "had the effect of withdrawing from the Legislature the ability to vest judicial power in any body and of concentrating in the court system all judicial power not expressly bestowed elsewhere by the Constitution." 11 Cal. 3d at 41, 520 P.2d at 38, 112 Cal. Rptr. at 814 (emphasis in the original). This clearly excluded local agencies. The Bixby rule was therefore apphed to the local retirement board's denial of service-connected death benefits to the widow Coreen Strunsky.

The separation of powers clause provides that "[p]ersons charged with the exereise of one power may not exercise either of the others except as permitted by this Constitution." CAL. Consr. art. III, $\$ 3$ (emphasis added). See, e.g., Skelly v. State Personnel Bd., 15 Cal. 3d 194, 539 P.2d 774, 124 Cal. Rptr. 14 (1975); Kirby v. Alcoholic Beverage Control Appeals Bd., 7 Cal. 3d 433, 498 P.2d 1105, 102 Cal. Rptr. 857 (1972); Boreta Enterprises, Inc. v. Departinent of Alcohohic Beverage Control, 2 Cal. 3d 85, 465 P.2d I, 84 Cal. Rptr. 113 (1970); Southern Cal. Jockey Club, lne. v. California Horse Racing Bd., 36 Cal. 2d 167, 223 P.2d 1 (1959); DeERING, supra note 11, \$\& 5.675.68, app. A. After Strumsky, only the relatively few decisions of agencies specifically granted judicial authority by the constitution remained outside the scope of the fundannental vestcd rights doctrine. The legislature responded in 1976 by making judicial review of local agency decisions available under section 1094.5. Ch. 276, § 1, 1976 Cal. Stats. (currently codificd at CAL. Civ. Proc. Code $\S 1094.5$ (West Supp. 1980).

On its face, the Tex-Cal conclusion that the legislature may give finality to agency dccisions based on substantial evidence "whether or not the California Constitution provides for that agency's exercising judicial power," 24 Cal. 3d at 346, 595 P.2d at 585, 156 Cal. Rptr. at 7, contradicts the court's holding in Strumsky limiting legislative delegation of "judicial power." The conflict is merely superficial. In contrast to the due process context, the phrase "judicial power" in the separation of powers cases has represented the court's flexible threshold between adjudicatory activities properly conducted solely by courts and those also permittcd to be exercised by agencies.

Prior to its 1936 decision in Standard Oil v. State Bd. of Equahization, 6 Cal. 2d 557, 59 P.2d 119 (1936), the court had employed a functional distinction between "quasi-judicial" and "judicial." The assumption was that an agency's ascertainment and application of facts to the law, pursuant to the enabling statute, was a properly delegated legislative act, but that the writ of certiorari, on its face applicable only to judicial decisions, was nevertheless an appropriate remedy to the extent that an agency decision was "judicial im its nature." Suckow v. Alderson, $182 \mathrm{Cal}$. 247, 249, 187 P. 965, 966 (1920) (suspension of beense to practice medicine, though judicial in nature, not an exercise of "judicial power of the state" under article VI, § 1). In Standard Oil, however, the court concluded that the writ only apphed to constitutional judicial acts, thereby confusing that practical framework. But six years after Standard Oil the court still pressed the "quasi" distinction: "[I]t is not the fact-finding power alone . . . [but rather] the faets found plus the order based thereon depriving a person of a property right which is the full exercise of judicial power." Laisne v. California State Bd. of Optometry, 19 Cal. 2d 831, 841, 123 P.2d 457, 465 (1942).

Clarifying its analysis of the judiciary clause in Strumsky, the court expressly avoided "the tern 'quasi-judicial' - an adjective used im some opinions and by some commentators to indicate the peculiar adjudicatory powers possessed by administrative agencies. . . . [T] The question here is the extent to which true judicial powers are and can be vested in local agencies.' "11 Cal. 3d 28, 42 n.14, 520 P.2d 29, 38 n.14, 112 Cal. Rptr. 805, 814 n.14 (1974).

Moreover, section 1094.5 permits admission of additional evidence on independent judgment review only im certain exceptional circumstances, signifying the legislature's recognition of the distimction. See note 50 supra. A contrary assumption, that fact-finding itself is a strictly judicial function, would have required admission of relevant new evidence in any circunstance.

That no practical difference exists between the powers of ordinary statewide agencies and those of agencies exercising constitutionally-conferred judicial authority suggests that the judicial/quasi-judicial distinction is a rhetorical device to preserve the judiciary's theoretical authority 


\section{B. A Single Substantial Evidence Standard}

The Tex-Cal court was satisfied that the procedural features of the ALRA were sufficient to fulfill due process requirements. ${ }^{74}$ Since California's $\mathrm{APA}^{75}$ mandates a procedural format substantially equivalent to that of the ALRA,${ }^{76}$ Tex-Cal implies that the legislature may amend section 1094.5 to give finahity to findings of fact, supported by substantial evidence, of any state agency covered by the APA or of any agency required to offer similar procedures under statutory or constitutional law.

Such an amendment merits serious legislative consideration. A single substantial evidence standard is sufficiently flexible to allow close scrutimy on review even where important rights are imvolved. Use of the simgle standard would bring California practice into step with the general federal trend away from judicial intrusion into substantive agency decisionmaking in reliance upon greater procedural safeguards imposed at the administrative level. ${ }^{77}$

The independent judgment test as applied does not necessarily protect important rights. While the Bixby rule is rooted in the notion that only an independent review can rescue fundamental vested rights from "exclusive administrative extinction," "78 the opinion itself suggests an anomaly by juxtaposing judicial deference to agency licensing expertise and nondeference in revocations. In terms of the fact-finding function itself, variations in agency expertise surely do not turn on whether the rights involved are vested or fundamental. The danger of an agency's "aroused zeal of scrutiny" present as well in license demals, where unpopular applicants nay be similarly investigated. ${ }^{80}$ Moreover, as pointedly illustrated in McDon-

rather than an actual restriction on the activities of agencies. In this context, therefore, the factfinding function has been viewed as quasi-judicial. Thus, the court's approval in Tex-Cal of the legislature's confirmation of the finality of Board findings supported by substantial evidence did not violate previously established limits on delegation of judicial power under the separation of powers clause.

74. The Board is required by statute to issue a complaint stating charges; the person charged may file an answer and appear im person to testify before an administrative law officer who must issue written findings, conclusions, and recommendations; the Board may take further testimony or hear argument, and based on a preponderance of the evidence must state its findimgs of fact when it issues its order. CAL. LAB. CoDE $\$ \S 1160.2-1160.3$ (West Supp. 1980).

75. CAL. Gov'T Code $\$ \S 11502-11518$ (West Supp. 1980).

76. Cal. Lab. Code $\$ \S 1140-1166.3$ (West Supp. 1980).

77. See JAFFe, supra note 24 , at $618-23$, and text accompanying note 100 infra.

78. 4 Cal. $3 d$ at 144,481 P.2d at 252, 93 Cal. Rptr. at 244.

79. Id. at 147, 481 P.2d at 254, 93 Cal. Rptr. at 246.

80. Indeed, Justice Mosk announced that he did not "choose to be foreclosed in the future from considering whether a rejected applicant, like a disciplined licensee, has been demied fundamental rights. I would apply substantially the same standards of review to both." $I d$. at 161,481 P.2d at 264, 93 Cal. Rptr. at 256 (concurring opinion). 
ough v. Goodcell, ${ }^{81}$ sonie license denials do in fact effect a deprivation of vested fundamental rights but nevertheless are reviewed under the substantial evidence standard. ${ }^{82}$

Nor do practical distinctions between the two standards indicate that only the independent judgment test provides adequate protection for important rights. Both require complete review of the record, including conflicting evidence. In cases where the court finds that there is relevant evidence that could not have been produced or was improperly excluded by the agency, section 1094.5 provides that the court may remand to the agency for reconsideration in substantial evidence cases. In independent judgment cases, the court may hear such evidence without renianding. ${ }^{83}$ In both cases, therefore, relevant evidence is included in the record. Because the court's discretion in both situations is limited to those specific instances given in the statute, the category of evidence the court is permitted to hear in independent judgment cases is not broader than that heard by an agency upon remand in substantial evidence cases.

The critical difference appears when evidence involves the issue of credibility. There nnay well be an advantage in having the reviewing court decide these points given the possibility of agency bias toward its particular "mission." The importance of this situation to the preservation of fundanrental vested rights is mitigated by its infrequent occurrence. Moreover, it may even be counteracted in those cases reviewed by an appellate court rather than a trial court, since an appellate court is less experienced than the agency in judging credibility. ${ }^{84}$ Given an agency's practiced expertise within its particular jurisdiction, credibility issues in particular are arguably more safely resolved by the agency than by any judicial authority.

A second and pervasive problem lies in distinguislimg the application of the substantial evidence and independent judgment standards in practice. Under the former, the court is directed to sustain the agency's findings if supported by substantial evidence on the whole record. ${ }^{85}$

81. 13 Cal. 2d 741, 91 P.2d 1035 (1939).

82. See text accompanying notes $25-28$ supra.

83. Cal. Civ. Proc. Code $\S 1094.5(\mathrm{e})$ (West Supp. 1980). See State v. Superior Court (Veta) 12 Cal. 3d 237, 524 P.2d 1281, 115 Cal. Rptr. 497 (1974) § 1094.5(e) [then (d)] (permits discovery regardless of the review standard employed).

84. At least one early commentator pressed for remand to the agency even in independent judgment cases, arguing that agencies were designed to take all evidence, that the court is not required by section 1094.5 to take additional evidence, that the writ of mandamus is discretionary and not a petitioner's right, that judicial review is still available following agency reconsideration, and that in any case the court's role is that of review. Netterville, Judicial Review: The "Independent Judgment" Anomaly, 44 CALIF. L. Rev. 262 (1956) [heremafter cited as Netterville].

85. Cal. Civ. Proc. Code $\$ 1094.5$ (c) (West Supp. 1980). This is identical to the federal requirement: "The substantiality of evidence must take into account whatever in the record fairly 
Under the latter, the court must reweigh the evidence, apply its independent judgment, and sustain the agency's findings if supported by the weight of the evidence. ${ }^{86}$ This distimction has been described as that between judging the reasonableness of the agency's inferences on the one hand (substantial evidence), and their correctness on the other (mdependent judgment). ${ }^{87}$ Since both instances require weighing the evidence for its value, it is difficult to perceive how im practice a judge might conclude that a decision is "reasonable" if a contrary inference is nevertheless more probable, i.e., "correct." 88 Whether a court resists the subtle leap from one standard imto the next may depend more on factors such as the court's confidence in the agency, the court's experience in the field, and the degree of techincal specialization involved in the case than on the presence of fundamental vested rights.

Aside from the blurred line between the two standards, or perhaps because of it, the substantial evidence test as applied allows sufficient flexibility for the protection of rights now requiring review by independent judgment. ${ }^{89}$ State courts do not limit their review to the "verbalistic formula" prescribed by a statute, which is generally understood to be directory rather than mandatory. ${ }^{90}$ In this regard the Cali-

detracts from its weight." Universal Camera Corp. v. NLRB, 340 U.S. 474, 488 (1950). In the earlier California cases the whole-record requirement was largely ignored by the courts, which instead would consider only the evidence supporting the agency's decision to determine whether it was substantial. Netterville, supra note 84, at 583 (1956). This "isolation approach" was firmly discredited by the California Supreme Court in LeVesque v. Workmen's Compensation Appeals Bd., 1 Cal. 3d 627, 638 n.22, 463 P.2d 432, 440 n.22, 83 Cal. Rptr. 208, 216 n.22 (1970), and again in Bixby, 4 Cal. 3d at 149 n.22, 481 P.2d at 255 n.22, 93 Cal. Rptr. at 247 n.22.

86. Cal. Civ. Proc. Code $\$ 1094.5$ (c) (West Supp. 1980).

87. Netterville, supra note 84 , at 279.

88. Noting this difficulty, Professor Jaffe has warned that:

[t]he judge must, therefore, be vigilantly aware of what he is doing [in a substantial evidence review] and stop short of such an exercise of power. . . It requires subtle, disciplined intellectual discrimination, and because this is so a judge can conceal from himself, and make it difficult for critics to prove, that he has permitted his predilection to determine the worth of the challenged inference."

JAFFE, supra note 24, at 602-03.

89. In a study of 188 cases reviewed by federal courts of appeals under the substantial evidence test, the standard was largely indistinguishable from the "clearly erroneous" test used to review district court decisions and permitting a court to set aside a decision found to be against the weight of the evidence. Cooper, Administrative Law: The "Substantial Evidence" Rule, 44 A.B.A.J. 945 (1958). Both basic facts and inferences were freely reviewed by the courts, and often reweighed and overtumed if contrary to the "solid sense of the entire record." Id. at 1002 (quoting Victor Products Corp. v. NLRB, 208 F.2d 834 (D.C. Cir. 1953). Not only did different circuits find a broad range of "substantiality," but within circuits the various agencies received various treatment. Rather than a deviation, this practice is in keeping with the Supreme Court's recognition that the standard "inay afford grounds for certitude but cannot assure certainty of application." Universal Camera Corp. v. NLRB, 340 U.S. 474, 488-89 (1951).

90. CoOPER, supra note 89, at 733-34. "Rarely is the statutory directive so narrow and precise as to prevent a court from making the rcview as broad or as narrow as to the court seems proper under the particular circumstances." Id. at 664. See also Jaffe, Judicial Review: Question of Fact, 69 HARv. L. REv. 1020, 1056 (1956): 
fornia cases involving agencies that exercise constitutional judicial authority are illustrative, because decisions concerning important rights are reviewed exclusively under the substantial evidence standard. ${ }^{91} \mathrm{Le}$ Vesque v. Workmen's Compensation Appeals Board ${ }^{92}$ involved a denial of an application for disability benefits. While the claim was pending, LeVesque had no inconie. The court's opimion contained an extensive examination of the facts, concluded that "[i]n essence, the referee's report confronts petitioner with the grisly choice of obeying the medical advice of his treating physician or risking further injury by following the inedical views of the referee," ${ }^{93}$ and remanded to the board. The substantial evidence test as applied in this mstance was in effect a substitution of the court's judgment on the facts. ${ }^{94}$

A conclusion that the substantial evidence standard is flexible does not imply that it is unschooled. The critical determinant of the intensity of review under either standard is the court's confidence in the agency as a decisionmaker. This in turn depends upon a range of factors in addition to the importance of the right involved: the technical or specialized nature of the issues, the amount of procedural protections afforded at the agency level, the harshness of the penalty imposed, the gravity of the alleged error, and the political pressures and bias at the agency level..$^{95}$ That these factors are in the nature of judicial

If a court is disposed to drive ahead to a single unified concept of scope of review, it will

find it easy to ignore or "interpret" phrases [such as "clearly erroneous" or "weight of the evidence"] which are at best so essentially imprecise, so ultimately dependent on the tone and mood of judicial apphication. Courts will narrow broad phrases as they will broaden narrow ones.

91. See note 73 supra.

92. 1 Cal. 3d. 627, 463 P.2d 432, 83 Cal. Rptr. 208 (1970).

93. Id. at 640,463 P.2d at 441,83 Cal. Rptr. at 217.

94. 7 Cal. 3d 433, 498 P.2d 1105, 102 Cal. Rptr. 857 (1972).

The malleability of the standard was again displayed in Kirby v. Alcoholic Beverage Control Appeals Bd., 7 Cal. 3d 433, 498 P.2d 1105, 102 Cal. Rptr. 857 (1972). In Kirby the hearing examiner recommended the grant of a liquor license; the department denied it; the appeals board reversed the departinent; the supreine court reversed the appeals board, finding the department's decision to be supported by substantial evidence; but three Justices, dissenting, found insubstantial evidence.

95. In Universal Camera, the Court noted in passing that a weight of the evidence standard has been rejected by the Attorney General's Committee on Administrative Procedure for two reasons. First, in the words of the committee, " '[s]ubstantial evidence' may well be cquivalent to the 'weight of evidence' when a tribunal in which one has confidence and which had greater opportunities for aceurate determination has already so decided." Second, because "administrative tribunals would be turned into hittle more than media for transunission of the evidence to the court," the value of expert adjudication would be destroyed. 340 U.S. at 480 n.12. See S. BREYER \& R. Stewart, Administrative Law ANd Regulatory Policy, 184-88 (1979); CoOper, supra note 25, at 667-72; JAFFE, supra note 24, at 623; Leedes, Understanding Judicial Review of Federal Agency Action: Kafkaesque and Langdellian, 12 U. RICH. L. REV. 469 (1978) (finding a reciprocal relationship between scope of review issue and threshold review issues, including jurisdiction, standing, ripeness, exhaustion of remedies, all of which turn on five factors: nature and degree of injury, nature of question presented, obviousness of agency error as it relates to person seeking 
rather than legislative doctrines is appropriate in light of the inevitable role of the court as a generalist and a balancer of legislative and executive prerogatives. ${ }^{96}$

Even under the independent judgment standard, the reviewing court's judgment as to the facts will thus be "independent" only to the extent that the court perceives its competence to exceed that of the agency. As originally formulated, the independent judgment test included the rule that "considerable weight should be given the findings of experienced administrative bodies made after a full and formal hearing, especially in cases involving technical and scientific evidence."97 Although this presumption was undermined by the court's subsequent decisions expanding the scope of review, ${ }^{98}$ it was explicitly reasserted when the court in Tex-Cal einphasized that the Board is "one of those agencies presumably equipped or informed by experience to deal with a specialized field of knowledge, whose findings within that field carry the authority of an expertness which courts do not possess and therefore inust respect." 99 The court thus aligned itself with the nodern federal trend toward a uniform substantial evidence review, which has generally been adopted to the extent that procedural protections are provided at the agency level. ${ }^{100}$

relief, opportunity for extra-judicial relief and ability of court to provide remedy, and impact of judicial imtervention on orderly conduct of governmental busimess).

96. "The scope of judicial review is ultimately conditioned and determined by the major proposition that the constitutional courts of this country are the acknowledged architects and guarantors of the integrity of the legal system." JAFFE, supra note 24 , at 589.

97. Drummey v. State Bd. of Funeral Directors, 13 Cal. 2d 75, 86, 87 P.2d 848, 854 (1939). Justice Traynor lias suggested that this element would make the distinction between the independent judgmeut and substantial evidence tests "more artificial than real." Dare v. Board of Medical Exammers, 21 Cal. 2d 790, 809, 136 P.2d 304, 314 (1943) (dissenting opinion). The presumption was not codified in section 1094.5.

98. The expansion reached its zenith with the de novo review announced in Laisne v. California State Bd. of Optometry, 19 Cal. 2d 831, 123 P.2d 457 (1942). Justice Traynor finally concluded that the presumption has "only such force as the superior court wishes" to give it. Moran v. Board of Medical Examiners, 32 Cal. 2d 301, 319, 196 P.2d 20, 31 (1948) (dissenting opinion). By 1960 it was "safe to conclude that this language is sinuply hortatory." Kleps, supra note 73, at 577.

99. 24 Cal. 3d at 346, 595 P.2d at 585, 156 Cal. Rptr. at 7 (quoting the United States Supreme Court's remark pertaining to the Labor Relations Board in Universal Camera Corp. v. NLRB, 340 U.S. 474, 488 (1950)).

100. See JAFFe, supra note 24, at 618-23. The federal APA allows de novo review in unspecified cases. 5 U.S.C. $\$ 706$ (1976). Significantly, the Supreine Court has construed this to apply when agency fact-finding procedures are inadequate, presumably a rare situation. Citizens to Preserve Overton Park, Inc. v. Volpe, 401 U.S. 402 (1971). The Court's intention of halting judicial intrusion into agency activities was recently illustrated in Vermont Yankee Nuclear Power Corp. v. Natural Resources Defeuse Council, 435 U.S. 519 (1978), holding that courts may not impose stricter procedural requirements for rule-making proceedings than those required by the APA.

The California Supreme Court has also evidenced a shift from direct control of administrative action to institutional controls. E.g., Topanga Ass'n for a Scenic Community v. County of 
Given a single standard for review of fact-finding, the court may still exercise its independent judginent in other ways to protect important rights. Section 1094.5 authorizes the court to independently determine "whether the respondent has proceeded without, or in excess of jurisdiction; whether there was a fair trial; and whether there was any prejudicial abuse of discretion." 101 The last clause includes instances in which the agency "has not proceeded in a inanner required by law [or] the order is not supported by the findings." 102 In addition, the court continues to protect against abridginent of an individual's constitutional rights by applying its independent judgment to cases in which such a claim is made. ${ }^{103}$ Given the detailed procedures imposed upon administrators by the California Court where fundannental rights are concerned, and the flexibility of the substantial evidence standard, the statutory independent judgment test is rapidly becoming a form without content. Section 1094.5 should be arnended to delete it. ${ }^{104}$

Los Angeles, 11 Cal. 3d 506, 522 P.2d 12, 113 Cal. Rptr. 836 (1974) (local agency must compile analytic findings, explain grounds of decision); LeVesque v. Workmen's Compensation Appeals Bd., 1 Cal. 3d 627, 463 P.2d 432, 83 Cal. Rptr. 208 (1970) (detailed findings required); Walker v. City of San Gabriel, 20 Cal. 2d 879, 129 P.2d 349 (1942) (agency decision must be based on more than merely hearsay evidence). The legislature has taken the same approach. For example, the court's application of the Bixby rule to the revocation of doctor privileges in Anton v. San Antonio Community Hosp., 19 Cal. 3d 802, 567 P.2d 1162, 140 Cal. Rptr. 442 (1977), was emasculated by the legislature's ainendinent of section 1094.5 to preclude independent judgment review of private liospital board decisions except when the petitioner alleges discrimination. CAL. Civ. Proc. Code $\$ 1094.5$ (d) (West Supp. 1980).

Futhermore, effective July 1, 1980, a new state Office of Administrative Law will review agency rule-nuaking activities "to ensure that they are written in a comprehensible manner, are authorized by statute and are consistent with other law." CAL. Gov'T CODE § 11340(d) (West Supp. 1980).

101. Cal. Crv. Proc. Code $\S 1094.5(b)$ (West Supp. 1980).

102. For example, even after three tiers of agency liearings had determined that a liquor license of a bar should be revoked, the supreme court reversed in Boreta Enterprises, Inc. $1 . D_{C}$. partment of Alcoholic Beverage Control. Confirming the board's discretion to protect the "public welfare," the court nevertheless used its independent judgment as to the propriety of topless waitresses, implying that the board liad responded to its "private morality": "[A] bar is not a church." 2 Cal. 3d 85, 101, 465 P.2d 1, 12, 84 Cal. Rptr. 113, 124 (1970). As a constitutionally authorized adjudication, the board's decision was only subject to a substantial evidence review. See also Topanga Ass'n for a Scenic Community v. County of Los Angeles, 11 Cal. 3d 506, 522 P.2d 12, 113 Cal. Rptr. 836 (1974); Harris v. Alcolrolic Beverage Control Appeals Bd., 62 Cal. 2d 589, 400 P.2d 745, 43 Cal. Rptr. 633 (1964); Western Air Linies, Inc. v. Schutzbank, 258 Cal. App. 2d 218, 66 Cal. Rptr. 293 (2d Dist. 1968).

103. Adcock v. Board of Educ., 10 Cal. 3d 60, 513 P.2d 900, 109 Cal. Rptr. 676 (1973) (teacher transferred allegedly in retaliatiou for exercise of first amendment rights); Bekiaris v. Board of Educ., 6 Cal. 3d 575, 493 P.2d 480, 100 Cal. Rptr. 16 (1972) (teacher allegedly dismissed because of political activities).

104. California equal protection principles also support the use of a simgle standard. "A person may not be deprived of life, liberty, or property without due process of law or denied equal protection of the laws." CAL. CoNST. art. I, \& 7(a). The constitution also provides that "(a) [a]ll laws of a general nature have uniforn operation. (b) A local or special statute is invalid in any case if a general statute can be made applicable." CAL. CoNST. art. IV, § 16. Generally, these provisions are the equivalent of the federal equal protection clause, but are independent of it and 
sometimes broader. See Gay Law Students Ass'n v. Pacific Tel. \& Tel. Co., 24 Cal. 3d 458, 468, 595 P.2d 592, 598, 156 Cal. Rptr. 14, 20 (1979); McGlothen v. Department of Motor Vehicles, 71 Cal. App. 3d 1005, 140 Cal. Rptr. 168 (1st Dist. 1977); Department of Mental Hygiene v. Kirchner, 62 Cal. 2d 586, 588, 400 P.2d 321, 322, 43 Cal. Rptr. 329, 330 (1965). Although in older cases the California Supreme Court did not find equal protection violations "if any state of facts could be conceived which would support it," Whittaker v. Superior Court, 68 Cal. 2d 357, 368, 438 P.2d 358, 367, 66 Cal. Rptr. 710, 719 (1968), more recently the court has employed the less deferential command "that statutory classifications bear soine substantial relationship to an actual, not 'constructive,' legislative purpose." Brown v. Merlo, 8 Cal. 3d 855, 865-66 n.7, 506 P.2d 212, 219-20 n.7, 106 Cal. Rptr. 388, 395-96 n.7 (1973) (censuring California's autounobile guest statute, which precluded recovery by nonpaying passengers as opposed to all others neghigently injured in automobile accidents). In addition, the court has not hesitated to use a higher standard than that imposed by the United States Supreme Court concerning "suspect classifications" and "fundamental rights" that compel a strict scrutiny standard of analysis of equal protection questions. E.g., Serrano v. Priest, 18 Cal. 3d 728, 557 P.2d 929, 135 Cal. Rptr. 345 (1976), cert. denied, 432 U.S. 907 (right to education compels strict scrutiny review under California Coustitution, though not under federal Constitution, San Antonio Independent School Dist. v. Rodriguez, 411 U.S. 1 (1973).

In contrast to the negative phrasing of the federal fourteenth amendment, the California provisions are an affirmative statement of the legislature's obligation to draft laws that have consistent and general application. In Mojave River Irrigation Dist. v. Superior Court, 202 Cal. 717, 262 P. 724 (1927), for example, the court examined a provision in the Water Commission Act giving parties an original action in superior court following denial or grant of water appropriation permits by the commission. The statute directed the trial court to confine its order to desiguated forms of judgment. The supreme court concluded the statute violated the equal protection provisions of the constitution, for two reasons: (1) no "sufficient reason" supported granting permit apphicants "this special forn of access to courts of justice as distinguished from all other persons who seek permits or privileges of many sorts from one or other of the numerous boards or officials similarly functioning," and (2) the existing general laws were "entirely adequate to deal with the controversies of those who are claiming or seeking to exercise conflicting rights in or to the use of waters of the state," $i d$. at $727-28,262$ P. at 728 .

The two standards given in section 1094.5, as applied by the courts, are distinguished according to the rights affected by the agency decision. The Tex-Cal decision, however, allows the legislature to provide for only one standard of review for an agency, regardless of the privileges it curtails or determines in a particular case. Similarly situated complainants can invoke different standards of review, determined not by the nature of their rights but by the agency having jurisdiction to adjudicate the case. The legislative and judicial justifications for the limited standard of review of ALRB decisions are the extensive due process protection provided at the agency level and the streamlined nature of judicial review. See text accompanying notes 61-64 supra. This rationale, however, is not sufficient to distinguish the ALRB fron, for example, the Fair Employment Practices Commission, which is empowered to impose similar sanctions, using similar procedures, CAL. LAB. CODE $\S \S 1422.5,1424,1426,1427$ (West Supp. 1980), yet is reviewed under section 1094.5 and is thus subject to independent judgment review im appropriate cases. CAL. Gov't CODE $§ \S 11501,11523$ (West Supp. 1980). See Northern Inyo Hosp. v. Fair Employinent Practices Comm'n, 38 Cal. App. 3d 14, 112 Cal. Rptr. 872 (4th Dist. 1974). Similarly, public service employees have access to independent judgment review. E.g., Pipkin v. Board of Supervisors, 82 Cal. App. 3d 652, 147 Cal. Rptr. 502 (3d Dist. 1978) (policeman); Estes v. City of Grover City, 82 Cal. App. 3d 509, 147 Cal. Rptr. 131 (2d Dist. 1978) (policeman); Lake v. Civil Serv. Comm'n, 47 Cal. App. 3d 224, 120 Cal. Rptr. 452 (5th Dist. 1975). But of. Turner v. Board of Trustees, 16 Cal. 3d 818, 548 P.2d 1115, 129 Cal. Rptr. 443 (1976) (probationary school eniployee has no fundamental vested right to be rehired for ensuing school year); CAL. Gov'T CODE $\S 3542$ (c) (West Supp. 1980) (findings of Public Employment Relations Board deemed conclnsive if based on substantial evidence on the whole record).

The ALRA was desigued "to ensure peace in the agricultural fields by guaranteeing justice for all agricultural workers and stability in labor relatious" and was "intended to bring certainty and a sense of fair play to a presently unstable and potentially volatile condition in the state." 


\section{IV}

\section{CONCLUSION}

The imphications of the gaps in the Tex-Cal opinion may be of greater consequence for California administrative law than the holding itself. While its result is sound, the Tex-Cal court's neglect of the salient constitutional issues leaves the contimued vahitity of the Bixby rule in doubt. The suggestion that administrative determination of fundainental vested rights may now be conclusive, if supported by substantial evidence, directly conflicts with the Bixby constitutional reasoning.

By freeing the scope of review question from its entanglement in constitutional doctrine, however, the court has opened a path toward a workable single standard. Adjudications of constitutional and nonconstitutional agencies, as well as license denials and revocations, are currently reviewed differently irrespective of the underlying rights at stake. Amending section 1094.5 to provide a substantial evidence standard of review in all cases in which due process is afforded at the agency level would eliminate this anomalous double standard. The California legislature would do well to address the probleins implicit in the Tex-Cal decision by enacting a uniform standard of review for all agency adjudications subject to due process requirements.

Jamin Hawks*

1975 Cal. Stats., ch. 1, \& 1 (Third Ex. Sess.). This concern applies to all situations involving large nunbers of unionized workers. Fair play among all workers and owners would be proinoted by a single review standard.

* B.A. 1975, University of California, Santa Cruz; third-year student, Boalt Hall School of Law. 